\title{
Marx on nineteenth-century colonial Ireland: analysing colonialism as a dynamic social process
}

$\mathrm{D}_{\mathrm{s}=\mathrm{s}}^{\mathrm{i}}$ iscussion of the relationship between Ireland and colonialism has often revolved around similarities and differences between the Irish situation and other, more iconic, examples of colonised societies. This tendency has been partially encouraged by the prominence within Marxian scholarship of dependency theory, which contends that the underdevelopment of colonial societies is due primarily to their integration into the capitalist world economic system. In this analysis, all colonised societies can be characterised by this integration into world capitalism, and consequently share a common source of exploitation and disadvantage. This perspective has often located its source in Marx's writings on India and, crucially for our current concern, Ireland. This article explores a different perspective on colonialism which the authors believe can be found in Marx's consideration of the Irish situation.

This discussion will centre on the 'Outline of a report on the Irish question to the communist Educational Association of German Workers in London'. ${ }^{1}$ While essentially comprised of notes, the document constituted the basis of a report that took an hour and a half to deliver ${ }^{2}$ - enough time to develop a sophisticated argument by today's academic standards. It will be argued that the report contains a number of provocative and under-discussed perspectives on the process of colonialism. The first is the evolution of the Irish colonial project through a succession of regimes that differ one from the other; consequently, it would not be surprising to find colonial regimes differing substantially from one place to another. Secondly, Marx discusses in some detail the effect of colonialism on the character of Irish agriculture in the nineteenth century. Marx does not neglect the impact of deindustrialisation under imperial integration, and the report contains several widely cited observations in this regard. However, Marx goes beyond the identification of the absence of industrial development to discuss the specific local dynamics of what is there: the Irish agricultural economy. Finally, Marx introduces the idea of colonialism having an ecological dimension through the effective export of nutrients from Irish soil. Thus, colonialism can violate the physical reproducibility of the colonised society as well as its economic, political and social integrity.

1 Karl Marx, 'Outline of a report on the Irish question to the communist Educational Association of German Workers in London, December 16, 1867' in idem and Frederick Engels, Ireland and the Irish question (Moscow, 1978), pp 136-49.

2 Ibid., p. 555, n. 110. 
In the early hours of 11 September 1867 , Colonel Thomas Kelly and a companion, Captain Timothy Deasy, were arrested in Manchester. Kelly had assumed the military leadership of the abortive Fenian uprising the previous March. A week later, on 18 September, a party of men - mostly drawn from the local Fenian organisation - ambushed the prison van in which the two were being transferred, and succeeded in liberating both men. In the mêlée, a shot fired into the van perhaps in an attempt to break the lock - killed a police sergeant, Charles Brett. Both Kelly and Deasy escaped, eventually making their way to the United States. Three Fenians were apprehended on the spot. An indiscriminate police trawl through the Irish communities in Manchester led to the arrest of many more men. Two of these were charged with the murder of Sergeant Brett, along with the three captured at the scene. ${ }^{3}$ In the instant the fatal shot was fired, the centre of the controversy surrounding the Fenian effort to separate Ireland from the United Kingdom by force shifted decisively to the English side of the Irish Sea.

The question as to how to respond to the Fenian challenge exercised not only the authorities in Britain, but the leaders of the workers' movement. The incident itself, and the conduct of the subsequent trial, were seen by British radicals as endangering working-class unity. Anti-Irish feeling among the English working class, it was feared, would be inflamed by the Brett killing (and to a certain extent it was). At the same time, the men on trial received considerable support and sympathy from the large Irish communities in British cities, most of whose members were poor and working class. ${ }^{4}$

At a meeting of the Reform League on 23 October, a heated debate broke out during which George Odger and Benjamin Lucraft - also members of the International Working Men's Association (I.W.M.A.) - defended the Fenians and their right to use physical force. ${ }^{5}$ On 2 November Marx wrote to Engels:

You will have seen what a row 'our people' kicked up in the Reform League. I have sought in every way to provoke this manifestation of the English workers in support of Fenianism. ${ }^{6}$

The issues became even more pressing when, despite varying levels of doubt as to culpability in each case, all five men were found guilty on 13 November, and were condemned to die. On 19 November Marx urged a discussion of the Fenian question at a meeting of the general council of the International. ${ }^{7}$ Minutes from the meeting seem to show unanimous support for the Fenian movement and the right of the Irish to revolt against British rule, as well as sympathy for the Fenian programme. ${ }^{8}$ On Marx's proposal, the discussion was adjourned until the next

3 Accounts can be found in T. W. Moody, The Fenian movement (Dublin, 1968); Robert Kee, The green flag, (3 vols, London, 1972), ii; R. V. Comerford, The Fenians in context: Irish politics and society, 1848-82 (Dublin, 1985); John Newsinger, Fenianism in midVictorian Britain (London, 1994); and Oliver P. Rafferty, The Church, the state and the Fenian threat, 1961-75 (Basingstoke, 1999).

4 See esp. Newsinger, Fenianism.

5 Ibid., p. 61.

6 Marx to Engels, 2 Nov. 1867 (idem \& Engels, Ireland \& the Irish question, p. 153).

7 Marx \& Engels, Ireland \& the Irish question, p. 552.

8 Minutes of the meeting of council and members and friends of the association, 19 Nov. 1867 (ibid., pp 485-9). 
meeting, apparently to allow him time to prepare his position. In the meantime, the general council issued a memorial, written by Marx, to the secretary of state urging commutation of the sentences.

The next meeting took place on 26 November 1867, three days after the executions of three of the convicted men (one had been pardoned, and the sentence of another commuted). Marx had prepared notes for a speech which would 'soberly analyze the state of affairs and the movement.' Fearing that in the aftermath of the executions and the resulting passions around the subject, he 'would be forced to hurl revolutionary thunderbolts', Marx yielded the floor to Peter Fox. Marx felt that, under the circumstances, Fox, as an Englishman, was better suited to addressing the matter. ${ }^{9}$ The development of Marx's full position on the Fenian question was to await his address to the German Workingmen's Association on 16 December. Some of the themes of this address were anticipated in a letter to Engels on 30 November 1867. In it, Marx observed a curious English misunderstanding of the colonial situation of Ireland:

What the English do not yet know is that since 1846 the economic content and therefore also the political aim of English domination in Ireland have entered into an entirely new phase ... What can be more ridiculous than to confuse the barbarities of Elizabeth and Cromwell, who wanted to supplant the Irish with English colonists (in the Roman sense), with the present system, which wants to supplant them by sheep, pigs and oxen! ... Clearing of the Estate of Ireland! is now the one purpose of English rule in Ireland. ${ }^{10}$

It is remarkable that Marx suggests that the English did not know the precise nature of their colonising campaign in Ireland in the post-Famine period. It cannot be because the English (we presume the government) simply did not reside in Ireland; rather, it must have to do with the complex structure of the colonising process, which shields its character from empirical observation, even by its protagonist. In developing this suggestion, it is possible to better elaborate upon Marx's understanding of colonialism.

At this stage, one may observe from the above quotation that Marx conceptualised the colonial relationship between Britain and Ireland as operating not in a static fashion but as passing through 'phases' of development. In addition, the latest one - identified as 'clearing of the estate of Ireland' - dates from 1846. This particular phase is contrasted with an earlier phase of the colonial relationship during the historical periods of Elizabeth and Cromwell. Already, Marx can be observed conceptualising the colonial relationship between England and Ireland as one with definite historical roots but which is ongoing at the time Marx is writing. Despite its ongoing character, however, this colonial process is capable of taking different forms, or 'phases', in different periods. Indeed, these phases may be so distinctive that nothing could be 'more ridiculous' than to confuse them.

Along the way, Marx identifies another phase from before the 1846 'clearing of the estate of Ireland'; this occurs between 1801 and 1846, and is dominated by the presence of rack-renting and middlemen:

The system of 1801-1846, with its rack-rents and middlemen, collapsed in 1846. The repeal of the Corn Laws, partly the result of or at any rate hastened by the Irish famine, deprived Ireland of its monopoly of English corn supply in normal times. Wool and meat became the slogan, hence the conversion of tillage to pasture. Hence from then onwards systematic

9 Marx to Engels, 30 Nov. 1867 (ibid., pp 156-7).

${ }^{10}$ Ibid., pp 156-8. 
consolidation of farms. The Encumbered Estates Act, which turned a mass of previously enriched middlemen into landlords, hastened the process. ${ }^{11}$

In this passage, Marx moves on to analyse the 'clearing of the estate of Ireland' phase more concretely as a systematic process made up of a number of discrete historical events, parliamentary enactments, and long-run market trends and agricultural practices. While Marx identifies colonial domination as a primarily political process, in this passage he emphasises the economic elements of the process. Crucially, while this process manifests itself in the aforementioned concrete entities and events, abstractly considered it is essentially a colonising process, and one that is not immediately recognisable in its concrete phenomenal forms, especially, according to Marx, by the English government. By contrast, it is certainly there for those that have to live in it - the Irish: 'Clearing of the Estate of Ireland is now the one purpose of English rule in Ireland. The stupid English government in London knows nothing of course itself of this immense change since 1846. But the Irish know it. ${ }^{12}$

\section{III}

It can be noted from the discussion above that Marx has no hesitation in considering the history of Ireland in a colonial context. Subsequently, Marxism has been to the forefront in locating Ireland within colonial-development literature. This tradition has its origin in the important place that Ireland held, along with India, in Marx's thinking on colonialism. This subsequent Marxist tradition has generally concentrated on how colonialism can hinder the economic development of the colonised economy. In the Irish case, most have concentrated on how Ireland was deindustrialised by Britain to create the essential condition for the 'development of underdevelopment'. This relationship of dependent development has become the most influential representation of the colonial relationship between Great Britain and Ireland. Kenzo Mohri has suggested that this colonial relationship is an early example of 'dependent development'. ${ }^{13}$

Ivan Vujacic, interpreting Marx's view of colonialism, saw Ireland as the classic case of colonial domination having had a detrimental effect on economic development, as opposed to the positive effect it had in India:

In this sense, colonialism plays a progressive role up to the point when it destroys the precapitalist mode of production and creates the conditions for overcoming underdevelopment (India), after which it becomes an obstacle to development of these countries (Ireland). ${ }^{14}$

Anthony Brewer is even more explicit in his interpretation of Marx's analysis of the colonial relationship between Britain and Ireland as centring on, and primarily involving, capitalist penetration:

Marx argued that Ireland's poverty and misery compared with England's status as the leading capitalist centre, were not caused by any internal difference in the prior mode of

${ }^{11}$ Ibid., pp 157-8.

${ }^{12}$ Ibid., p. 158.

${ }^{13}$ Kenzo Mohri, 'Progressive and negative perspectives of capitalism and imperialism' in Ronald Chilcote (ed.), Imperialism: theoretical directions (Amherst, New York, 2000), p. 134.

${ }^{14}$ Ivan Vujacic, 'Marx and Engels on development and underdevelopment: the restoration of a certain coherence' in History of Political Economy, 20, no. 3 (1988), p. 483. 
production, but by external (English) oppression and exploitation. The expulsion of the peasantry and the creation of capitalist farms ... followed essentially the same course as in England, though it was carried out with even greater brutality. ${ }^{15}$

In Brewer's account, Marx emphasises the capitalist nature of colonialism in creating conditions of underdevelopment and by making the Irish economy dependent on the British economy. This interpretation of Marx on Ireland was one of the crucial influences on Gunder Frank when he founded the 'dependency' framework in the 1970s. This basic interpretation in relation to Ireland is fleshed out in the work of a number of writers in the Marxian tradition. Accounts of Irish history in these terms can be found in Ronnie Munck ${ }^{16}$ and John Kurt Jacobsen. ${ }^{17}$ The definitive - and the most sophisticated - account of the history of the development of underdevelopment in Ireland can be found in Denis O'Hearn's The Atlantic economy: Britain, the U.S. and Ireland. ${ }^{18}$

What is common to the array of differing interpretations of Marx's understanding of Ireland's colonial relationship with Britain is the tendency to emphasise one element of that relationship as the 'prime mover' of colonialism. The problem with this theoretical tendency is that other 'variables'- occurring in concrete situations and over differing historical periods - tend to be either ignored as unconnected, or to appear as mere consequences of the determining 'prime mover'. The result of this search for a single determining dynamic anchoring Marx's conceptualisation of the Irish situation is that this abstraction of determination within the colonial relationship must necessarily be taken out of context. 'Context' here is meant in a double sense: both as the changing historical reality of Ireland over the long period of colonialism, and as the textual context of Marx's own more theoretical approaches to the Irish question.

\section{IV}

Although Marx and Engels did not publish a completed work on Ireland, the contention that Marx never engaged in a systematic investigation of the Irish question is mistaken. ${ }^{19}$ Ireland claimed the attention of Marx and Engels for over fifty years. ${ }^{20}$ According to Anthony Coughlan, a published volume of their collected writings on Ireland runs to 500 pages. ${ }^{21}$ It contains a hundred pages of Engels's unfinished history of Ireland, and eighty pages of Marx's preparatory notes on the course of Irish history from 1776 to 1801 . The rest of the material is mainly comprised of articles and extracts from their published books, letters,

${ }^{15}$ Anthony Brewer, Marxist theories of imperialism: a critical survey (2nd ed., London, 1990), p. 48.

${ }^{16}$ Ronnie Munck, The Irish economy: results and prospects (London, 1993), pp 1-23.

${ }^{17}$ John Kurt Jacobsen, Chasing progress in the Irish Republic (Cambridge, 1994), pp 45-50.

${ }^{18}$ Denis O'Hearn, The Atlantic economy: Britain, the U.S. and Ireland (Manchester, 2001).

${ }^{19}$ See, for instance, Stephen Howe, Ireland and empire: colonial legacies in Irish history and culture (Oxford, 2000), p. 3.

${ }^{20}$ Ellen Hazelkorn, Marx and Engels on Ireland: an annotated checklist, American Institute for Marxist Studies bibliographic series, no. 15 (New York, 1981), p. 2.

${ }^{21}$ Anthony Coughlan, 'Ireland's Marxist historians' in Ciaran Brady (ed.), Interpreting Irish history (Dublin, 1994), p. 291. 
excerpts from speeches and reports, and more than fifty unpublished manuscripts. The published articles, mostly from newspapers, date from 1843 to 1895 , and number fifty-four in the checklist compiled by Ellen Hazelkorn. The personal correspondence between Marx and Engels, and between them and friends and family, in which Ireland is referred to in some detail totals 123 letters, dating from 1855 to 1894 . However, Marx and Engels were especially absorbed in the politics and study of the Irish question from 1867 to 1872 , which was dominated by the Fenians and their aborted rising. This coincided with the First International, and Marx and Engels spoke on Ireland and the Fenians to the council of the International Working Men's Association on nineteen occasions between 1869 and 1872.

Although the above exemplifies the extent of their commitment to the Irish question, it is their manuscript work that reveals the depth of the two men's research. Marx and Engels used a considerable range of material on Ireland. Engels tended to engage in more historical research, and used secondary material from published histories of Ireland. For example, in preparation for his book on Irish history, Engels listed 200 books to be consulted. ${ }^{22}$ Marx tended to refer to more contemporary material, such as newspapers - both English and Irish (the Freeman's Journal, The Irishman) - census reports, governmental reports (for example, Poor Law inspectors' reports), Blue Books, published parliamentary debates and pamphlets.

The discrete nature of Marx's published observations on the Irish situation in newspapers, journals, Capital volumes I and III, and in his letters to Engels and others over the years ${ }^{23}$ does not alter the fact that Marx and Engels formed a substantive theoretical position on the Irish question. This was clearly displayed on 16 December 1867 when, finally, Marx finally gave his ninety-minute speech on the Irish crisis to German immigrants in London. To prepare for this, Marx wrote a manuscript that ran to fourteen printed pages. ${ }^{24}$ It is exclusively about Ireland, and not primarily concerned to illustrate concrete instances of difference from the more capitalistic development of Britain (something he does in Capital). Although it was mostly written in note form, Marx, as the authors hope to demonstrate, was able to construct a theoretical framework that allowed him to provide a systematic analysis of the Irish question. His immediate concern was to find the basis on which the English working-class movement could enthusiastically support the Fenian demand for Irish independence. Characteristically, Marx believed this could only be based on a sophisticated understanding of the nature of the colonial relationship between Britain and Ireland.

Two other short pieces are relevant. Firstly, the 'Notes from an undelivered speech on Ireland', ${ }^{25}$ which Marx had intended making on 26 November 1867, constitute the basis for the speech delivered in December of that year. Secondly, there exists an anonymous record of the December speech that summarises Marx's main points. ${ }^{26}$ These notes clearly form the starting point for the later report. The

${ }^{22}$ Hazelkorn, Marx and Engels on Ireland, p. 38.

${ }^{23}$ Marx \& Engels, Ireland \& the Irish question.

${ }^{24}$ Marx, 'Outline', pp 136-49.

${ }^{25}$ Karl Marx, 'Notes for an undelivered speech on Ireland' (idem \& Engels, Ireland \& the Irish question, pp 130-5).

${ }^{26}$ Karl Marx, 'Record of a speech on the Irish question delivered by Karl Marx to the German Workers' Educational Association in London on December 16, 1867' (idem \& Engels, Ireland \& the Irish question, pp 150-3. 
present article attempts to explicate this framework from the report itself and its two supplementary documents. The authors suggest that this particular intellectual endeavour holds the key not only to Marx's understanding of colonialism in the Irish context but also to providing a more complex theoretical framework for understanding colonialism in general.

\section{V}

The report was read before the Communist Educational Association of German Workers in London on 16 December 1867. In organising the presentation of the data for this talk, Marx divided his third section into passages with the following sub-headings:

a) The English in Ireland before the Protestant Reformation

b) Protestant epoch. Elizabeth. James I. Charles I. Cromwell. Colonisation plan (16th and 17th centuries)

c) Restoration of the Stuarts. William III. Second Irish revolt, and the capitulation on terms

d) Ireland defrauded and humbled to the dust. 1692-July 4, 1776

e) 1776-1801. Time of transition

The final sub-heading (not preceded with a letter) is ' $1801-1846$ '. Section IV is entitled 'The period of the last 20 years (from 1846). Clearing of the Estate of Ireland'.$^{27}$ In chronological order, Marx identified watersheds in the colonial relationship between Ireland and Britain, and these headings provide an important insight into how his thinking developed. However, the colonial regime is crucial, as this is what Marx is attempting to account for as the relationship moves through these watersheds:

Here is what baffles the English: they find the present regime [emphasis added] mild compared with England's former oppression of Ireland. So why this most determined and irreconcilable form of opposition now? What I want to show [...] is that the regime [emphasis added] since 1846, though less barbarian in form, is in effect [as] destructive ... ${ }^{28}$

From this observation near the beginning of the report, one can see that Marx deepens the concept of colonialism with the idea of the regime. He uses this concept of regime as the initial theoretical tool to examine not only the colonial relationship between Britain and Ireland but, crucially, how that relationship changed over time as it passed through its various historical watersheds.

Although the colonial regime is located at the political level, Marx also attempts to understand how this particular political regime impacted on Irish civil society:

Hence, I shall give only a few [facts], firstly, to clarify the difference between the present and the past and, secondly, to bring out a few points about the character of those who are now called the Irish people. ${ }^{29}$

Marx's discussion of 'the character of ... the Irish people' is very much determined by the particular stage (or phase) in the development of the colonising process.

${ }^{27}$ Marx, 'Outline'.

${ }^{28}$ Ibid., p 136.

${ }^{29}$ Ibid., p. 137. 
For example, in the initial stage, the original English colonists married into the native Irish population at all levels of society, but especially at the top, where the Anglo-Normans married into the Irish noble families to such an extent that in the next wave/phase of colonising - with its particular Protestant badge of conquest - the 'Catholic Anglo-Irish fought the English alongside the natives' ${ }^{30}$ In the eighteenth century, the penal laws attempted the 'Anglicanisation' of proprietary title, though the actual consequence - the 'Catholicisation' of the Irish people was the opposite of the intended aim:

Experiment to coerce the mass of the Irish nation into the Anglican religion. Catholics deprived of vote for members of parliament.

This penal code intensified the hold of the Catholic priesthood upon the Irish people. ${ }^{31}$

Marx pauses to summarise the 'result of English terrorism':

English incomers absorbed into the Irish people and Catholicised.

The towns founded by the English Irish.

No English colony (except Ulster Scotch) but English landowners. ${ }^{32}$

According to Marx, the strategies mentioned above, along with others (to be discussed later), created across the long lifespan of the colonial process in Ireland were developed within the political regime but impacted on all aspects of Irish civil life. Colonialism as a social form penetrated many institutions and structures of everyday life, including political representation, the legal code between the landlord and tenant, the economy, the population structure, emigration, the ecology of agricultural production, and the physical and mental health of the native population. Therefore, although colonialism comes into being at the political level, it permeates all other levels of the Irish social formation, and takes on specific forms appropriate to these levels. Like Marx, the authors begin at the political level.

\section{VI}

In briefly reviewing the historiography of Marx's ideas on the Irish colonial question, the authors discovered a trend of reducing the dynamics of the colonial relationship to the working out of an 'essential' prime mover. This tendency to abstract a reified essential structure from a complex moving process very much determines the character of the lessons gleaned from Marx's report of 1867. This tendency to abstract a single fundamental dynamic has found inspiration in two dramatic statements concerning deindustrialisation: 'She [England] struck down the manufactures of Ireland, depopulated her cities and threw the people back upon the land', ${ }^{33}$ and 'Every time Ireland was about to develop industrially, she was crushed and reconverted into a purely agricultural land. ${ }^{34}$

On the superficial level and without context, these passages are open to the misinterpretation that the relationship is a geographic one between countries or

${ }^{30}$ Ibid.

${ }^{31}$ Ibid., p. 140 (italics as in original).

${ }^{32}$ Ibid. (italics as in original).

${ }^{33}$ Ibid., p. 139.

${ }^{34}$ Ibid., p. 142. 
competing regions, with England holding the upper hand. However, this spatialised determination can be challenged by putting these quotations back into the original context of the report. In contextualising these quotations, it is possible to discover what Marx meant by 'She [England]'. The first quotation comes from section III, subsection $d$ of the report, which Marx entitled 'Ireland defrauded and humbled to the dust: 1692-July 4, 1776'. Here, he discussed the effect of British mercantile policies on Ireland:

1698. The Anglo-Irish parliament (like obedient colonists) passed, on the command of the mother country, a prohibitory tax on Irish woollen goods export to foreign countries.

1698. In the same year, the English parliament laid a heavy tax on the import of the home manufactures in England and Wales, and absolutely prohibited their export to other countries. She struck down the manufactures of Ireland, depopulated her cities and threw the people back upon the land. ${ }^{35}$

Accordingly, the spatialised entity of 'England' becomes politically concretised in the institution of the English parliament, and can therefore be theoretically identified as a political part of the colonising regime. However, it should be pointed out that in the same quotation, the English parliament was not the only institution operating in the colonising regime in this particular historical period. Marx also identified the Anglo-Irish parliament in Dublin as another institution of the colonising regime. In this phase of development, these two distinct institutions formed part of the colonising regime, and were, according to Marx, able to work in unison in dominating the economy of Ireland. However, this consensus of approach became undone when conflict broke out between them, as the following from the same section (III: d) testifies:

1698: Molyneux pamphlet for the independence of the Irish parliament (i.e., the English colony in Ireland) against the English. Thus began the struggle of the English colony in Ireland and the English nation. ${ }^{36}$

Thus, factions of the colonising regime can potentially struggle with one another. This insight has an important implication for scholars' understanding of power relationships within the regime, and between the regime and civil society. The power of the colonising regime is not absolute. Though power is shared between the institutions of the regime, power relationships can also be challenged from within the regime itself by competing institutional factions. Consequently, the strategies imposed on Irish civil society were not necessarily the product of a consensus among the institutions of the regime. In reality, the relationship between the colonising institutions of the political regime were often conflictual as a result of tension and contradictory strategic orientations. Colonialism within this Marxist framework cannot be a unidirectional power relationship played out between a centre (political) dominating a periphery (economic or civil society, or both). In fact, complex internal power struggles can emerge within the colonising regime itself as well as between the colonising state institutions that make up that regime, and the civil society they are attempting to dominate.

The second quotation on deindustrialisation comes from section III, subsection $e$ of the report: '1776-1801. Time of Transition'. In this historical period - in quite stark contrast to the mercantilist interventionism of the previous period - the

35 Ibid., p. 139 (italics as in original)

${ }^{36}$ Ibid. (italics as in original). 
demise of Irish industry is due to the introduction of free trade between the two economies. This situation came about with the Act of Union, which Marx saw as the culmination of the factional struggle between the two parliaments:

Anglo-Irish House of Commons voted for the Act of Union passed in 1800. By the Legislature and customs union of Britain and Ireland closed the struggle between the AngloIrish and the English. The colony itself protested against the illegal Act of Union. ${ }^{37}$

Therefore, the specific determining factor, as suggested by Marx, in the deindustrialisation of Ireland in the nineteenth century was not due to economic conditions (either internal or external) but to a watershed reached within a long-running struggle between separate parliamentary institutions in the regime, where one institution was able to use its power to close down the other. Therefore, although the consequences of this political struggle were economic, the actual immediate determining factor must be located at the political level. As a consequence, the analytical focus on a 'prime mover' of the industrial self-interest of the metropolitan economy is not appropriate in understanding the complex changing relationships between the colonising institutions within the political level and their relationships with the Irish economy and civil society in general. The 'prime mover' approach must therefore be rejected as a form of inappropriate reductionism.

It is now necessary to take a closer look at the obverse side of deindustrialisation: 'throwing the people back on the land' and the converting of Ireland 'into a purely agricultural land'.

\section{VII}

The analysis of the origins of deindustrialisation in a succession of colonial political regimes is about identifying the source of a crucial absence in the Irish social formation. What was actually waiting for the native Irish population on the land was a rack-renting landlord caste. Marx articulated this in the following way:

Ireland is therefore purely agricultural: 'Land is life' (Justice Blackburne). Land became the great object of pursuit. The people had now before them the choice between the occupation of land, at any rent, or starvation. System of rack-renting. ${ }^{38}$

In locating the importance of rack-renting in the relationship between the landlord class and their tenants, Marx moved his analysis onto examining the role that landlordism played in the colonising process. The imposition of landlordism on the native Irish and their land through the plantations of the sixteenth and seventeenth centuries meant that a landlord-tenant relationship mediated the relationship between the colonising elites and the native Irish. And in monopolising access to the land, the colonising gentry were able to exploit the native Irish by rack-renting them. Marx continually asserted throughout this material that the only successful aspect of the English colonisation of Ireland was the following: "All that the English government succeeded in doing was to plant an aristocracy in Ireland. 39

Accordingly, landlordism becomes not only the pivotal relationship in the

${ }^{37}$ Ibid., p. 141 (italics as in original).

38 Ibid., p. 142 (italics as in original).

39 Marx, 'Record', p. 151. 
process of British colonisation of Ireland and the one that 'bathes the rest' 40 of the colonising institutions, it is also seen as a vital institution within the political regime that was unique to Ireland. The uniqueness of the landlords' position within the colonising regime was ironically determined by the failure of other strategies to effectively colonise the Irish in the period of the plantations. The initial strategy that failed was developed during the reign of Elizabeth I: 'The plan was to exterminate the Irish at least up to the river Shannon, to take their land and settle English colonists in their place. ${ }^{41}$ By the end of the seventeenth century and the beginning of the eighteenth, this practice of bringing British farmers into Ireland was dropped: "All notions of "planting" the country with English and Scotch yeomen or tenant farmers were discarded. ${ }^{42}$ Consequently, with the failure of this specific strategy, coupled with others - such as the attempted 'Anglicanisation' of the native Irish Catholic population through the penal code - the new tenurial structure of rack-renting came about because it was the only strategy that 'worked'.

This imposition of a landowning aristocracy upon Ireland allowed them - with the full backing of the military and police apparatus of the new state - to use their monopoly ownership of the land to exploit the native population in a rack-renting system. Again, Marx reiterated that the sole 'success' of the colonisation of Ireland was that 'They succeeded only to plant a landowning aristocracy. ${ }^{43}$ But the price to be paid by the colonising institutions of the British state for the continuing cooperation of this planted landowning class was that they become a powerful and relatively autonomous part of the colonising regime:

With the help of the Protestant penal laws, the new aristocrats received freedom of action under Queen Anne. The Irish parliament was a means of oppression. Those who were Catholic were not allowed to hold an official post, could not be landowners, were not allowed to make wills, could not claim an inheritance ... All these [measures] were means for robbing the Irish of their land ...4

This 'freedom of action' meant that the newly established landed gentry took over the other institutions of the state operating in Ireland for the purposes of their own particular colonising agenda. ${ }^{45}$ The consequence of this 'takeover' manifested itself in the landlords essentially protecting their own economic interests vis-à-vis their Irish tenantry by dominating and controlling the political and legal institutions of the state. During this period, statute after statue was passed by the Irish Protestant parliament for the benefit of the landlords when dealing with their Irish tenants; for example, 'the ejectment code' was enacted to expedite and facilitate the eviction of the tenant, to get rid of every formality and difficulty that protected the British tenant under English common law. Isaac Butt summarised the difference between the ejectment codes in Britain and Ireland:

${ }^{40}$ After a description by Marx: 'It is as though light of a particular hue were cast upon everything, tingeing all other colours and modifying their specific features as if a special ether determined the specific gravity of everything found in it'; Karl Marx, A contribution to the critique of political economy, ed. Maurice Dobb (Moscow, 1977), p. 212.

${ }^{41}$ Marx, 'Outline', p. 137.

42 Ibid., p. 139 (italics as in original).

43 Ibid., p. 137.

${ }^{44}$ Marx, 'Record', p. 150.

${ }^{45}$ See, for instance, Virginia Crossman, 'Colonial perspectives on local government in nineteenth-century Ireland' in Terrence McDonough (ed.), Was Ireland a colony? Economics, politics and culture in nineteenth-century Ireland (Dublin, 2005), pp 102-16. 
In England it is the duty of judges to administer law so as in every doubtful case to protect the tenant. In Ireland it has been judicially declared to be their duty in every doubtful case to facilitate his eviction. ${ }^{46}$

This legal form of colonial domination in the ejectment code is reflected throughout all aspects of the landlord-tenant relationship: distress, distrain, agricultural improvements, agricultural fixtures, restraints on leasing, and so on. These were legally constituted to buttress the position of the landlords vis-à-vis their tenants.

The degree of subordination of the tenant in this relationship extinguished the possibility of contractual (formal) equality that exists between the capitalist landlord and tenant. Instead, an essentially feudal mode of production was established in the Irish countryside through expulsion from, and re-entry to, the land of the native Irish tenantry. Ironically, this took place as feudal relations were fading from the English landscape. The feudal social form of production is a consequence of the complex process of colonialism creating personal discretionary powers for the Irish landlord class in its dealings with the native tenantry. In extracting the surplus product from the Irish direct producers through complex tenurial arrangements, the landlords not only feudalised the Irish legal system but also used these legal rights as a way of applying extra-economic coercion. ${ }^{47}$

The structural conditions determined by the use of extra-economic coercion caught Irish agriculture in a vice-like grip of feudal relations rather than the more dynamic possibilities potentially created by capitalist investment. As a consequence, the colonisation of Ireland was not determined by the capitalist mode of production, nor did it result in the emergence of the capitalist mode of production in Irish agriculture. What did emerge under the yoke of colonisation was the feudalisation of Irish agriculture - the only remaining sphere of production within which the vast majority of the Irish population could obtain access to physical subsistence.

This theoretical insight in the report permeated Marx's discussions on the Irish question in Capital. For example, in volume III, Marx writes with regard to the non-capitalistic nature of Irish agriculture:

We are not referring here to the conditions in which ground rent, the mode of landed property corresponding to the capitalist mode of production has a formal existence even though the capitalist mode of production itself does not exist, the tenant himself is not an industrial capitalist, and his manner of farming is not a capitalist one. This is how it is in Ireland, for example. ${ }^{48}$

The normal distribution of income under the capitalist mode of production did not exist in the Irish social formation:

Here the tenant is generally a small peasant. What he pays the landowner for his lease often absorbs not only a portion of his profit, i.e. his own surplus labour, which he has a right to as owner of his own instruments of labour, but also a portion of the normal wage, which he would receive for the same amount of labour under other conditions. ${ }^{49}$

${ }^{46}$ Isaac Butt, The Irish people and the Irish land: a letter to Lord Lifford (Dublin, 1867), pp 188-9.

${ }^{47}$ This argument is developed in more detail in Eamonn Slater and Terrence McDonough, 'Bulwark of landlordism and capitalism: the dynamics of feudalism in nineteenth-century Ireland' in Research in Political Economy, 14 (1994), pp 63-118.

${ }^{48}$ Karl Marx, Capital: a critique of political economy (3 vols, London \& New York, 1976-81), iii, 763.

${ }^{49}$ Ibid. 
The 'normal wage' and 'other conditions' which Marx is referring to in the above passage are those to be found within the capitalist mode of production. The extraeconomic coercion at the foundation of the feudal mode of production subverts the possibility of the 'normal' conditions of the capitalist mode of production emerging in the Irish social formation. In his report, Marx further expands on this tendency to hinder the development of the capitalist mode of production through the inability of the agricultural economy to reinvest capital back into the production process, and the subsequent exportation of this capital to Britain:

Middlemen accumulated fortunes that they would not invest in the improvement of the land, and could not, under the system which prostrated manufactures, invest in machinery, etc. All their accumulations were sent therefore to England for investment ... thus was Ireland forced to contribute cheap labour [through emigration] and cheap capital to building up 'the great works of Britain'. ${ }^{50}$

According to Marx, the amount of rent sent to absentee landlords, the amount of interest on mortgages, and the investment of Irish capital in England was many millions of pounds sterling. ${ }^{51}$ The crucial aspect of Marx's point in the above is not the amount actually sent to Britain to build up 'the great works of Britain' (an important focus of dependency theory), but, rather, the reasons why that capital had to be exported. Capital, which was extracted from Irish agriculture through rental returns, was not reinvested in the Irish economy partially because of the legal right of the landlord to appropriate improvements made by the direct producers - the tenants. According to William Neilson Hancock, these legal impediments to reinvestment of capital into the Irish economy were a direct consequence of feudal characteristics of the Irish legal system. ${ }^{52}$

Although this feudalisation began in the reign of Queen Anne, its legal presence was still in existence even after the Act of Union. This legal presence was one of the concrete links between the political regime of colonisation and its peculiar manifestation in the creation of a feudal landholding class on the ground:

State only a tool of the landlords ... After the Union the system of rack-renting and middlemen, but left the Irish, however ground to the dust, holder of their native soil. Present system, quiet business-like extinction, and government only instrument of the landlords (and usurers). ${ }^{53}$

Referring to the post-Famine situation, and concluding his analysis, Marx - it is recorded - made the following summation: 'The domination over Ireland at present amounts to collecting rent for the English aristocracy. ${ }^{54}$

With the continuing decline in industrial manufacturing at the beginning of the nineteenth century - when free trade came into effect as a consequence of the Act of Union - the rent relationship became the dominant one in the Irish economy. This manifested itself in its most explicit forms in the rack-renting and middlemen systems that reached their zenith in the pre-Famine period.

${ }^{50}$ Marx, 'Outline', p. 143 (italics as in original).

${ }^{51}$ Ibid.

52 William Neilson Hancock, Impediments to the prosperity of Ireland (London, 1850).

${ }^{53}$ Marx, 'Outline', pp 133-4.

${ }^{54}$ Marx, 'Record', p. 152. 


\section{VIII}

Marx analysed pre-Famine Ireland in the section entitled '1801-1846'. The 'occupation of land, at any rent, or starvation' ${ }^{55}$ was the dramatic dilemma facing the native Irish population in the early part of the nineteenth century because of the deindustrialisation of the Irish economy and the subsequent rise of the rack-renting system on the land. This life-and-death dilemma was created by the monopolistic position of the landowners, who since the plantations owned the entire surface area of Irish land, and used this situation to dictate legal and financial terms to their tenantry. The concrete manifestation of these institutional arrangements was to allow the landlords to charge enormous rents to their tenants - to rack-rent them. But it also allowed them to create a middleman system between themselves and the actual occupiers of the land. According to Marx,

It became a vital necessity to have land; big landowners leased their lands to speculators; land passed through four or five lease stages before it reached the peasant, and made the prices disproportionately high. ${ }^{56}$

The Irish legal system, under the control of the landlords, established the right to sublet estates to other landlords, and thus create subtenants. In this type of subletting (between landlords), the rent charged to the actual occupier (the direct producer of the rent) must cover all the rents of the various intermediate landlords (middlemen) as well as the head landlord. Consequently, within the middleman system, there was a tendency for each subletting to double the amount of rent charged to the next subtenant as the intermediate landlords attempted to replicate the same lifestyle of the head landlord. ${ }^{57}$ This non-market determination of the financial cost of subletting within the middleman system, coupled with the tenant's legal insecurity in the rack-renting system, reflected the particular social form of production in Irish agriculture, which can only be identified as feudal in character. Given the centrality of the implantation of the landlord class to the political domination of Ireland in this period, the process of colonisation takes on an economic form, in which extra-economic coercion dominates the economic relationships of Irish society. ${ }^{58}$

In drawing a distinction between the pre-Famine and post-Famine regime, Marx opens the possibility of finding a dynamic of change and transformation within the feudal mode of production itself. This dynamic can be found in the contrast between the strategies for the extraction of feudal rent in the two periods. The period before the Famine was dominated by the extraction of absolute rent. The period after the Famine was characterised by a relative-rental strategy. While Marx does not explicitly analyse the differences in this way, the distinction can be found elsewhere in his work. An absolute strategy of increasing rent involves increasing the amount of surplus labour extracted within existing production techniques and

55 Marx, 'Outline', p. 142 (italics as in original).

56 Ibid., p. 151.

${ }^{57}$ Kevin O'Neill in his study of County Cavan suggests that the ratio between the rent paid by the subtenant and the head tenant is 2:1: Family and farm in pre-Famine Ireland (Madison, W.I., 1984), p. 60.

58 Extra-economic coercion in the extraction of surplus labour is identified as the essential characteristic of feudalism in Ernesto Laclau, 'Feudalism and capitalism in Latin America' in New Left Review, no. 67 (May/June 1971), pp 19-38, and in Marx, Capital, iii, 926-7. 
levels of productivity. A relative-rental strategy pursues the expansion of rental income through the increase in productivity on the land.

The rack-renting and middleman system is an example of the absolute strategy. Rack-renting simply increases rental income by raising the rent and thereby forcing the tenant to devote more labour to the production of rent and less to the production of his own standard of living. The middleman system achieves the same goal more indirectly. The proliferation of subletting under the middleman system forces the final tenant onto smaller and smaller plots of land without corresponding reductions in rent. Indeed, the multiplication of intermediate landlords and the need to support them tended to increase the rent. In this way, absolutely more labour was devoted to supporting the landlord system..$^{59}$ Marx describes the end of this system in volume I of Capital:

The depopulation of Ireland has thrown much of the land out of cultivation, greatly diminished the produce of the soil, and in spite of the greater area devoted to cattle breeding, brought about decline in some of its branches, and in others an advance scarcely worth mentioning, and constantly interrupted by retrogressions. Nevertheless, the rents of the land and the profits of the farmers increased along with the fall in population, though not so steadily as the latter. The reason for this will easily be understood. On the one hand, with the throwing together of the smallholdings, and the change from arable to pasture, a part of the total product was transformed into a surplus product. The surplus product increased although there was a decrease in the total product of which the surplus product formed only a fraction. On the other hand, the monetary value of this surplus product increased still more rapidly than its actual quantity, owing to the rise in the price of meat, wool, etc., on the English market. ${ }^{60}$

\section{IX}

Marx begins the section entitled 'The period of the last 20 years (from 1846). Clearing of the Estate of Ireland' by suggesting that the 'new period' was ushered in by the potato blight (1846-47), resulting in starvation and the consequent exodus. 'Over one million die, partly from hunger, partly from diseases, etc. (caused by hunger). In nine years, 1847-55, 1,656,044 left the country.' ${ }^{61}$ The consequence was a revolution in agriculture: 'The revolution of the old agricultural system was but a natural result of the barren fields. People fled ... Hence, of course, the pooling of small leaseholds and substitution of pasturage for crop farming. ${ }^{\prime} 2$

The revolution Marx is discussing is the transition from an absolute-rental strategy to a relative one. ${ }^{63}$ The pooling of small leaseholds is about raising agricultural productivity through the creation of an optimal farm size allowing for the application of new techniques, mostly associated with plough husbandry. This increase in productivity in turn would allow for an increase in rental income. It is interesting to observe how Marx in the 'Notes' has conceptualised the initial phase

59 Slater \& McDonough, 'Bulwark of landlordism and capitalism'.

${ }^{60}$ Marx, Capital, i, 860.

${ }^{61}$ Marx, 'Outline', p. 144.

${ }^{62}$ Ibid.

${ }^{63}$ This argument is developed in more detail in Slater \& McDonough, 'Bulwark of landlordism and capitalism', pp 63-118. 
of the agricultural revolution following on from the Famine. The 'revolution' in the agricultural sphere of production seems to have occurred on two levels: firstly, a process of consolidation began, especially on those farms of under one to under fifteen acres; ${ }^{64}$ secondly, there was simultaneously a switch from crop production to livestock production, especially to the pasturing of cattle. But what is crucial to our analysis is what Marx observed next: 'However, soon circumstances arose whereby this became a conscious and deliberate system [emphasis added]. ${ }^{365}$

This 'system', associated with the new rental strategy, is, according to Marx, made up of a number of elements, some of which originate in the decision making of the political state. Accordingly, the revolution in Irish agriculture was now being determined by a new phase in the colonisation of Ireland. Mostly, these factors involved parliamentary enactments that either created institutions that encouraged the landlords to consolidate their estates - such as the Poor Law and Encumbered Estates Court - or abolished the monopoly position held by Ireland in supplying corn to Britain through the repeal of the Corn Laws. These concrete factors of the colonising process also included individual actions by the landlord class in reforming the landed estates through various concrete processes such as eviction, paid emigration, 'improving' agricultural techniques, and by preventing land subdivision among the tenantry. These political and landed-estate strategies of the colonising regime merged into one overriding aim: 'Clearing of the Estate of Ireland! is now the one purpose of English rule in Ireland.' 66

\section{$\mathrm{X}$}

According to Marx, there was an ecological consequence of the 'Clearing of the Estate': the colonisation of Irish soil. From 1861 until 1866, there was a dramatic decrease in cultivated land: cereal crops declined by 470,917 acres, green crops by 128,061 acres. However, even more interesting to Marx with regard to agricultural statistics was the decrease of yield per acre of every crop from 1847 until 1865. Oats decreased by 16.8 per cent, flax by 47.9 per cent, turnips by 36.1 per cent and, incredibly, the potato crop by 50 per cent. In 1851 the estimated average potato yield per statute acre was 5.1 tons, and this dropped to 2.9 tons in $1866 .{ }^{67}$ Marx suggested these statistics indicated that Irish soil was gradually losing its fertility:

${ }^{64}$ Marx, 'Notes', p. 133.

${ }^{65}$ Marx, 'Outline', p. 144.

${ }^{66}$ Marx to Engels, 30 Nov. 1867 (idem \& Engels, Ireland \& the Irish question, p. 158) (italics as in original).

${ }^{67}$ Marx, 'Outline', pp 145-6. The decline in productivity that Marx observed in the contemporary statistics has been confirmed in more recent historical work. The less intense cultivation involved in the switch from spade to plough husbandry after the Famine consequent on the consolidation of farms would have contributed to the fall-off in productivity. The fall in the amount of labour applied to the land was especially important (see Michael Turner, After the Famine: Irish agriculture, 1850-1914 (Cambridge, 1996), p. 29). The statistics would be impacted, however, by the fact that 1859 to 1864 was a period of agricultural depression brought on by poor weather conditions, which damaged output (ibid., pp 30-2). The point here is not the empirical accuracy of the argument but the way in which Marx integrates a number of levels of analysis in his treatment of the Irish colonial situation. 
'Since the exodus, the land has been underfed and overworked ... So result ... gradual deterioration and exhaustion of the source of national life, the soil. ${ }^{96}$

This tendency highlighted by Marx is an example of what he identified as a metabolic rift. John Bellamy Foster has recently rediscovered the 'green' Marx, which, he has argued, is centred around Marx's concept of the metabolic rift, which he borrowed from the German agricultural chemist, Justus Von Liebig. ${ }^{69}$ Following on from the work of Liebig, Marx suggested that a metabolic rift occurs when nutrients from the soil are naturally transferred to agricultural products in the process of growth and, as nutrients embodied in the commodity form, are then transported from their local ecosystems through trade to urban centres of consumption. When these embodied nutrients are consumed in the urban centres, they are subsequently excreted into the local urban waterways - in many cases, polluting these waterways. As a consequence of this spatial movement of the nutrients to these urban centres, they are lost to the local agricultural ecosystems because they are never 'traded' back to their original source. This causes a metabolic rift to occur in the rural ecosystem as the nutrients continue to leach out of their native environment into the physical structures of agricultural products, and if they are not replaced, there will be (gradual) deterioration in the fertility of the soil.

Marx, in Capital, volume I, suggested that this metabolic rift was happening to Irish soil, and was further caused by the process of colonialism:

[I]t must not be forgotten that for a century and a half, England has indirectly exported the soil of Ireland, without even allowing its cultivators the means of replacing the constituents of the exhausted soil. ${ }^{70}$

But as revealed in the present analysis, it is necessary to critically evaluate the social form Marx is referring to in the spatial entity, 'England'. In the report, Marx locates the determination of the metabolic rift at the economic level in its concrete forms of consolidation of landholding and the disappearance of conacre:

Since the exodus, the land has been underfed and overworked, partly from the injudicious consolidation of farms, partly because under the corn-acre system, the farmer in a great measure trusted to his labourers to manure the land for him. ${ }^{71}$

The consolidation of farms and the previous conacre were themselves, in Marx's view, mediated by the social form of the feudal mode of production. In consolidating landholdings, the landlord was able to appropriate more of the surplus product, and in doing so appropriated more nutrients that had to be traded (mostly to Britain) so that the surplus product could be realised in its concrete financial form: monied rent. This consolidation eliminated the conacre system, which was the final subletting in which labourers received a plot of land in exchange for a combination of labour and rent. Thus, through consolidation, the labour force responsible for recuperating the land was lost.

However, another aspect of the increase in the surplus product also impacts on the exportation of 'Irish soil' that Marx draws attention to: with the increasing

${ }^{68}$ Marx, 'Notes', pp 132-3.

${ }^{69}$ Foster's best articulation of this perspective is in his article for the American Journal of Sociology: John Bellamy Foster, 'Marx's theory of metabolic rift: classical foundations for environmental sociology' in American Journal of Sociology, 105, no. 2 (Sept. 1999), pp 3.66-405.

${ }^{70}$ Marx, Capital, i, 860.

${ }^{71}$ Marx, 'Outline', p. 146. 
decline in the population through emigration, less of the soil is given over to the physical subsistence of the population - a metabolic transfer of nutrients that is more likely to keep those nutrients not only in the country but also in the local ecosystems. Therefore, the social process of colonisation that manifests itself in the concrete forms of farm consolidation and the physical loss of nutrients from the Irish soil prompts Marx to make a conceptual link: 'So result: gradual expulsion of the natives, gradual deterioration and exhaustion of the source of national life, the soil. ${ }^{\prime} 72$

There is one more level that Marx investigates: the mental and physical health of the remaining native Irish population. He notes that 'whilst the population had decreased enormously' there was at the same time 'not only a relative, but an absolute increase in the number of deaf-mutes, blind, insane, idiotic, and decrepit inhabitants. ${ }^{73}$ Provocatively, Marx was reported to have attributed this decline in the Irish population's health directly to the metabolic rift in the colonised soil of Ireland:

With the exhaustion of the soil, the population has deteriorated physically. There has been an absolute increase in the number of lame, blind, deaf and dumb, and insane in the decreasing population. ${ }^{74}$

This final point links environmental factors with health issues, and, in doing so, projects Marx not only as an historical analyst of colonialism but also, perhaps, as a theorist of environmental modernity.

\section{$\mathrm{XI}$}

Marx concludes his report with a considered defence of the Fenian movement. He asserts that the Irish question is not simply a nationality question; rather, it is a question of 'land and existence'. ${ }^{75}$ Marx is contending that the attempted decolonising campaigns by the Fenians and other political movements of civil society were essentially about deconstructing the various concrete forms in which colonialism existed at several levels in the Irish social formation. As discovered in this analysis of Marx's framework, the abstract social process of colonialism moves through many concrete forms located on differing levels, such as the political, legal, economic, social and even ecological. The political is usually dominant because colonialism is inherently about the exercise of force within the political regime in order to attempt to subvert the 'natural' tendencies and laws of motion within the economy/civil society so as to continually reproduce particular colonising elites. Resistance to colonialism can operate at any of these levels, from the economic (movements for tenants' rights) to the cultural (language and sport), but the pivotal level is the political, where institutional arrangements are put in place that determine the specific concrete structures of the colonising process. Hence, for the Fenian movement, according to Marx, it is essential that 'Ruin or revolution is the watchword' ${ }^{76}$

${ }^{72}$ Marx, 'Notes', p. 133.

${ }^{73}$ Marx, 'Outline', p. 148 (italics as in original).

${ }^{74}$ Marx, 'Record', pp 151-2.

${ }^{75}$ Ibid., p. 152.

${ }^{76}$ Ibid. 
Subsequently, Marx and his family became enthusiastically involved in the movement for amnesty for the Fenian prisoners. The extent of this involvement is evident in a letter of 5 March 1870 to Laura and Paul Lafargue:

Here, at home, as you are fully aware, the Fenians' sway is paramount. Tussy [Marx's daughter Eleanor] is one of their head centres [leaders]. Jenny writes on their behalf in the 'Marseillaise' under the pseudonym of J. Williams. I have not only treated the same theme in the Brussels 'Internationale', and caused resolutions of the Central Council to be passed against their gaolers. In a circular, addressed by the Council to our corresponding committees, I have explained the merits of the Irish question. ${ }^{77}$

In the next paragraph, Marx indicates the universal importance he gave to the Irish struggle for independence:

To accelerate the social development in Europe, you must push on the catastrophe of official England. To do so, you must attack her in Ireland. That's her weakest point. Ireland lost, the British 'Empire' is gone, and the class war in England, till now somnolent and chronic, will assume acute forms. But England is the metropolis of landlordism and capitalism all over the world. ${ }^{78}$

The outbreak and failure of the Paris Commune in 1871, and the subsequent disintegration of the First International, preoccupied and disheartened Marx, and his interest in the Irish question lost urgency. ${ }^{79}$

\section{XII}

Marx's account of Irish history in the report indicates that there cannot be a general theory of colonialism, with a single 'prime mover', because colonialism depends on the conjunction of the forces operating in the political regime with those in the local economy and civil society. Therefore, Marx provides only a theoretical guide to conceptualising it as a social process. This conception creates the ability to trace the particular colonial tendencies operating within the specific colonised society. Accordingly, those theorists and historians who have exclusively conflated the determinations of colonialism with capitalistic expansion eliminate the possibility of discovering the subtle and often hidden ways in which colonialism impacts on local political institutions and those in civil society. What Marx provided in the report was a theoretical framework that allows scholars to go beyond the relatively narrow economic analysis of Marxian dependency theory: one that instead sees colonialism as a complex social process operating at differing levels within the social formation as these levels interact with each other in complex ways. This framework has the potential to lead to more fruitful work on specific colonialisms in the Marxian tradition.

What can be concluded from this examination of Marx's report of 1867 is that colonialism begat a feudal economy that lasted into the nineteenth century. The Cromwellian conquest introduced a British feudalism in Ireland at precisely the moment the English feudal aristocracy was losing its sway over British society.

${ }^{77}$ Karl Marx to Paul and Laura Lafargue, March 1870 (idem \& Engels, Ireland \& the Irish question, p. 404).

${ }^{78}$ Ibid.

79 John Newsinger, “'A great blow must be struck in Ireland": Karl Marx and the Fenians' in Race and Class, 24, no. 2 (1982), pp 151-67. 
The motivation for this settlement was more political than economic, its aim being to secure Ireland against rivals. Subsequently, strategic necessity forged a strong bond between Irish landed and British imperial interests. The absence of traditional ties left the peasantry without customary protections. The religious disability of the peasantry reinforced inequity in tenurial relations. While retaining power over a subordinated peasantry, the fitful character of industrialisation under various colonial regimes shielded the landlord class from challenges that would have emanated from a dynamic capitalist class. Thus, the colonial character of Irish agricultural relations advantaged the landlords in conflict with both the native peasantry and alternative elites. These institutional advantages maintained feudalism in Ireland into the nineteenth century.

Finally, Marx raised the possibility that the dynamic of colonial relations could push up against the limits of the physical environment. Colonial exploitation had the possibility of disrupting the reproductive processes involved in the recuperation of the soil through the recycling of essential nutrients. This underlines the necessity of a concrete analysis of colonial situations at multiple levels. This awareness of the colonisation of the ecosystem of Irish agriculture perhaps lends an extra layer of meaning to the end of the section entitled 'Clearing of the Estate of Ireland'. Marx concludes: 'In sum, it is a question of life and death. ${ }^{80}$

EAMONN SLATER Department of Sociology, National University of Ireland, Maynooth

TERRENCE McDonough Department of Economics, National University of Ireland, Galway

${ }^{80}$ Marx, 'Outline', p. 149. 